\title{
A snapshot of early childhood care and education in South Africa: Institutional offerings, challenges and recommendations
}

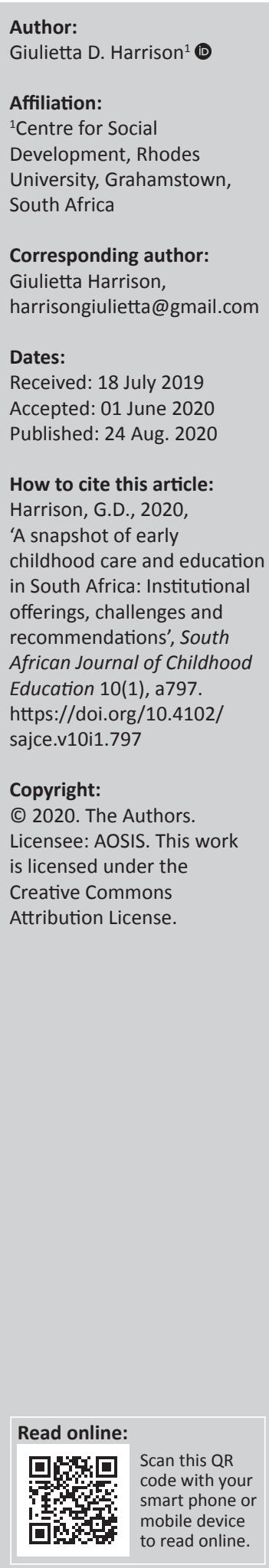

Background: This article draws from a research report on the Project for Inclusive Early Childhood Care and Education (PIECCE), which surveyed attitudes, training strategies, materials and entrance requirements across most relevant higher education institutions(HEIs), non-governmental organisations (NGOs) and technical and vocational education and training colleges (TVETs).

Aim: The aim of this study was to identify what institutions were offering in terms of training teachers in the birth-to-four age group, to identify the challenges and provide recommendations based on the findings.

Methods: Participatory action research was performed to generate data, which took the form of a Google survey, individual interviews and document analysis. These research tools were adjusted according to the requirements of the study, as and when necessary. The combination of the desktop study and the PIECCE report provided a comprehensive picture of South African early childhood care and education (ECCE), with particular emphasis on government funded training institutions and NGOs, as well as current challenges.

Results: Findings and recommendations are presented. The challenges include, amongst others, issues such as uneven geographic spread of ECCE offerings, lack of training skills, difficulties obtaining quality qualifications, dysfunctionality of accreditation bodies, misalignment between National Qualifications Framework (NQF) and HEI entrance requirements and poor remuneration of teachers.

Conclusion: A desktop study on institutional offerings, written as a collaborative effort across a variety of teacher-training institutions, evidenced that there are a number of fundamental issues in the sector. If the challenges can be resolved, the quality of ECCE training and accessibility can improve.

Keywords: institutional offerings; collaborative research; institutional collaboration; transformative pedagogy; action research; ECCE; ECD.

\section{Introduction}

Knowledge in the early childhood care and education (ECCE) sector is generally considered to be fragmented (ed. Harrison 2018). This is exacerbated by a lack of communication between stakeholders. The Department of Higher Education and Training (DHET) has in recent times shown a commitment to improving qualification offerings specific to early childhood and to bringing together this largely disjointed sector of education. One of the contributions was through the introduction of the Teaching and Learning Development Capacity Improvement Programme (T\&LDCIP) projects, in which one of the primary benefits was opportunities to bring together different voices and consolidate valuable information to frame the ECCE sector into a comprehensive training consortium. A desktop study that identified different ways in which governmental training institutions and non-governmental organisations (NGOs) provided for the needs of teachers or practitioners who wish to obtain qualifications in ECCE, assisted in achieving an overarching view of what was happening in this sector: a 'snapshot', if you will. This was essential in identifying gaps and challenges related to how training was done and who provided training. This is particularly important for shaping policy, programmes and training materials. Note that private training organisations are outside the ambit of this research.

\section{Contextualising early childhood in South Africa}

The African Charter on the Rights and Welfare of the Child (in Viviers 2014) stated that every nation should develop its own comprehensive national strategies to ensure that quality services 
are provided for the development of its children. This means that strategies, policies and resources must be put in place and co-ordinated to ensure successful development of the child. Much has been said about the first 1000 days of life and how these are the most important for children's development and future (Richter et al. 2012; Richter 2013; UNICEF 2017). 'When children do not receive the necessary input and support to promote their development during this critical period, it's very difficult and costly to help them catch up later' (Ilifa Labantwana 2017:4).

Relevant, age-appropriate learning through play is an important aspect of stimulating learning in the birth-to-four age group; consequently, it is imperative that South Africa has a well-trained workforce of early childhood teachers who can meet the needs of children. There are, however, many challenges that constrain a positive outcome. A significant number of children under the age of six do not have access to essential ECCE services such as clean running water, adequate nutrition and safe structures to learn in (Ilifa Labantwana 2017:6).

As a result of the vast difference in context, a distinction must be made between young children in rural areas and those in urban settings. The rural environment is often characterised by a lack of access to clinics, schools and adequate nutrition, which can lead to stunted growth. At national level, more than $20 \%$ of children under the age of five suffer from stunting or other health issues resulting from malnutrition (Berry, Dawes \& Biersteker 2013; Ilifa Labantwana 2017). Attempts have been made to address malnutrition through school feeding schemes, which traditionally provide one cooked meal a day. Despite the fact that many feeding schemes, such as 'JAM' or 'Lunchbox', provide schools with support, children continue to suffer. The problem lies in ECCE centres that close for school holidays, resulting in children no longer receiving daily porridge. In addition, many current feeding schemes operate more in urban or peri-urban areas than in rural settings. This places responsibility for nutrition back at the door of primary carers, such as parents, older siblings and grandparents.

The role of children's primary carers is central to their development. Ensuring that parents have knowledge and access to clinics has been a goal of the Department of Health which, in recent times, introduced an application ('app') called 'Momconnect'. The app provides mothers with a weekly text message ('sms'), starting during pregnancy and continuing into preschool, giving information on how to improve their child's health and stimulate learning. Using cellphone technology to support child development may seem like an odd choice for communities that are struggling to put food on the table, but most parents do make use of cellphones and, even in rural settings, parents have access to cellular reception through hubs set up in community centres. It can, therefore, be said that, even in settings where clinics, the traditional source of support for young mothers, are not easy to access, parents may be able to improve their knowledge by means of technological aids and cellphones in particular. However, this is dependent on parents knowing about the app in the first place, therefore the Department of Health needs to run 'road shows' to promote access to resources.

Another support for primary carers is the Child Social Grant (CSG), which was introduced in 1994. The CSG is meant to address inequalities that exist between homes across the socio-economic strata in South Africa. The CSG is intended to improve nutrition, health and education for children living in poverty. The CSG does, however, come with its own problems, such as difficulties with applications for the grant and parents not using the grant for its intended purpose (Khosa \& Kaseke 2017) . More careful monitoring of the CSG is necessary if the grant is to fulfil its intended purpose.

Overall, the reviewed literature evidenced a lack of data on all of the above-mentioned issues. Without this type of research, it is difficult to bring about change because the relevance and scope of problems are not sufficiently documented.

\section{Attitudes, policies and practices}

Quality ECCE is heavily dependent on suitably qualified practitioners who have in-depth understanding of what they are doing, why they are doing it and who reflect on how to continually improve their practice and adapt to challenges (Ebrahim, Killan \& Rule, 2011; Ebrahim, Okwany \& Berry, 2019; Peralto 2008; Wood 2013). The Project for Inclusive Early Childhood Care and Education (PIECCE) report and desktop study (ed. Harrison 2017, 2018) described a scenario that works against practitioners and their delivery of quality service; the problem relates to teacher training. This section delves into matters related to teacher training from the perspective of attitudes of teachers, policies that are in place and current practices in training teachers.

The desktop study revealed that teacher training has been pegged largely as vocational and occupational, with little academic involvement from higher education institutions (HEIs) beyond a Foundation Phase (FP) degree that may have a module that addresses the basics of early childhood development (ECD). It could be argued that the greatest need for teacher training was, and still is, amongst teachers residing in impoverished and rural areas where non-centre-based ECCE facilities often cater for working parents (Biersteker 2007; Ebrahim 2010; Ebrahim, Seleti \& Dawes 2013).

To date, NGOs have tended to dominate private provision of the Education, Training and Development Practices Sector Education and Training Authority's (ETDP SETA) National Qualifications Framework (NQF) Levels 4 and 5 qualifications in ECD, because many NGOs work in rural and impoverished areas. Non-governmental organisations took up the challenge and worked with 'practitioners' to provide a qualification through ETDP SETA (Biersteker \& Picken 2008; Mbarathi, Mthembu \& Diga 2016). 
Initial qualifications that were developed were Levels 1, 2, 4 and 5, with a later addition of Level 6 which often took the form of a Grade R diploma ${ }^{1}$ (ETDP SETA 2012; SAQA 2008). The PIECCE report (ed. Harrison 2017) established that, despite development of qualifications, there were issues of quality with regard to standards of training and roll out. Roll out is meant to take place either through DHET or via private training institutions registered with ETDP SETA. Difficulties arose with monitoring of the quality of training and implementation, a lack of knowledge about application for accreditation and dysfunctionality in ETDP SETA, resulting in training organisations offering courses but being unable to issue certificates. This has a profound impact on the reputation of NGOs as service providers and on participants' ability to benefit from qualifications.

A further concern was implementation of qualifications (Bridge 2016). Many student teachers come from deprived educational backgrounds that do not allow for a strong foundational knowledge and are required to learn in English, which is not their mother tongue. Consequently, the completion of NQF Levels 4 or 5 can take considerable time, and there is a high attrition rate. Additionally, the classification of these qualifications as vocational rather than professional has meant that practitioners are not able to register with the South African Council of Educators (SACE) and are therefore unable to earn the salary of a professional. The result is that, instead of professionalising the sector, it remains trapped in an informal and uncontrolled environment that does little to uplift the quality of education in the early pre-school years.

Technical and vocational education and training colleges (TVETs), previously known as further education and training colleges (FETCs), were implemented in 2002 and began to offer ECD NQF Levels 4 and 5 qualifications. This should have promoted the practice of HEIs' offering Level 4 or 5 qualifications and NGOs' issuing certificates timeously. The problem, however, is that there is little quality control across TVETs. The gap between NQF Level 5 and university entrance means that, although in theory this should be possible, many students are unable to progress to a degree from a Level 5 qualification. Poor access is further aggravated by students doing Levels 4 and 5 without a matric certificate, but HEIs require said document for entrance to an undergraduate degree. As in the case of NGOs, TVETs are at the mercy of ETDP SETA to issue certificates and therefore suffer the same lack of delivery with teachers not receiving the qualifications that are their due.

South Africa is often described as a country with many forward-thinking policies, which should result in rapid development (eds. Ebrahim, Okwany \& Barry 2019). Putting these policies into practice, however, has been difficult to achieve, according to the findings of the desktop study and the PIECCE report (ed. Harrison 2017, 2018; HSRC \& ELRU

1.The NQF consists of 10 levels with Levels $1-4$ equating to Grades $9-12$, Level 5 being at a higher certificate level and Level 6 at diploma level.
2010). At the heart of South Africa's policies related to ECCE are two core principles: (1) to redress the wrongs of the past and (2) to uphold the rights of the child (DBE 2001; DoJ 2005; DoE 2001; DSD 2014). It is important to pause to consider some of these policies because they help to illustrate this 'snapshot' of ECCE.

Taking into account that ECCE is a multi-stakeholder and multi-disciplinary sector, the policies examined were taken from a variety of government departments. The first was the National Health Act 60 (Department of Health and Welfare [DHW] 2003), which focusses on protection of the rights of particularly vulnerable groups. This policy makes provision for free healthcare services for pregnant women and children under the age of six. It further endeavours to address the issue of malnutrition and provision of basic nutrition. The Children's Act 38 (DSD 2005) has the direct aim of regulating ECCE systems and provides a framework of norms and standards for care and education in the early years. Key areas of this policy include children with disabilities, chronic illness, safety and child protection, and the role of parents in development of the child. The White Paper 6 on Inclusive Education (Department of Basic Education [DBE] 2001) was an attempt to put systems in place that would address early identification of children with learning difficulties, disabilities and/or at risk, to provide interventions within the first 1000 days, thereby improving potential for positive outcomes.

In 2006, the Guidelines for ECD Service Standards (DSD 2006) were designed to address a formalising of quality ECCE services through monitoring and evaluation. Three years later in 2009, the National Early Learning Development Standards (NELDS; DBE \& UNICEF 2009) set out to provide clear norms and standards related to what to expect in the birth-to-four age group. The National Integrated ECD Policy (DSD 2015) placed the emphasis on equitable access to ECCE services, funding streams, workforce development, essential packages and further quality assurance (Biersteker 2008). In the same year, the South African National Curriculum Framework for Children from birth-to-four years (DBE 2015a) provided guidelines for ECCE stakeholders, relating to six key areas, namely well-being, identity and belonging, communication, mathematics, knowledge and understanding of the world, and creativity.

A review of the current Policy on the Minimum Requirements for Programmes Leading to Qualifications in Higher Education for ECD Educators (PMRP) (DHET 2017) indicates a desire to professionalise the sector with particular emphasis on the birth-to-four age group. Many who work in this sector applaud this development, which has been lacking in the past (ed. Harrison 2017; DHET 2011; 2015). Figure 1 shows how the different policies fit into the preparation of teachers in the ECCE sector. Each policy provides teachers with guidelines on standards to aspire to, core principles to follow and what type of teacher they should become. 


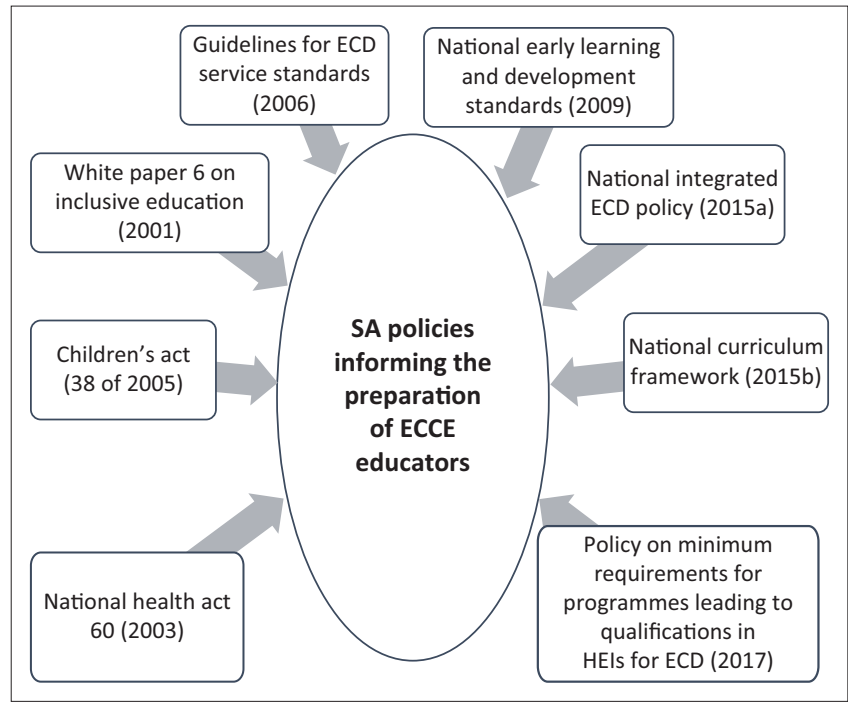

Source: Adapted from Harrison, G.D. (ed.), 2017, PIECCE report, Centre for Social Development, Rhodes University, Grahamstown.

FIGURE 1: South African policies informing preparation of early childhood care and education. ECCE, early childhood care and education; SA, South Africa.

The PMRP (DHET 2017) is a competency-based policy that suggests that teachers should be told what they need to know and do. The PMRP advocates 10 competencies that the teacher should aspire to. These include that teachers should, amongst others, have a professional mind-set, role and responsibility; understand and promote child development; promote learning in a variety of contexts; build family relations; facilitate learning through play; understand diversity and have leadership skills. Norms and standards, together with knowledge and practice standards, form the basis of ETDP SETA-accredited qualifications and, therefore, are not uncommon in South Africa (RSA 1996; 2014, 2015; SAQA 2008). However, this presents questions of how different training organisations offer teacher-training programmes, what this looks like and where teacher-training programmes are offered. It has further raised questions around quality of training, standardisation and articulation between qualifications. The relevant studies (ed. Harrison 2017, 2018) aimed to begin to answer some of these questions.

As mentioned, there are issues around articulation of qualifications within and between institutions. In addition, with government explicitly stating what quality looks like policy may not sufficiently allow for contextual differences (Spaull 2013). This is particularly important in South Africa because of the wide range of socio-economic contexts that require attitudes, policies and practices to be flexible and adaptive to context. The attitudes of teachers to their teaching environment, whether or not they choose to adopt a particular policy, and the quality of their implementation, are individual responses to complex circumstances (Britto, Yoshikawa \& Boller 2011). The fact that South Africa continues to perform poorly in the international arena, in tests such as PIRLS (Mullis et al. 2017), is indicative of the crisis in education that is as yet unresolved (Spaull 2013). The policies illustrate a transformative approach to pedagogy, which needs to be discussed further.

\section{Transformative pedagogy}

Part of the desktop study (ed. Harrison 2018) included looking at transformative pedagogy (TP), which aims to present the most current thinking about how to transform pedagogic approaches to realise quality ECCE. Transformative pedagogy is by its nature designed to bring about change. With South Africa's challenging history, the legacy of apartheid determines that the need for change remains great, as our progress in achieving positive outcomes for learners remains disappointing (Jansen 2012).

Transformative pedagogy draws from the work of Paulo Freire (1970) and uses his ideas, such as 'dialogic education' rather than 'banking education'. The traditional view of education sees the child not unlike a bank into which teachers deposit information, as if the child were an empty vessel. Dialogic education means that learners are actively involved in the learning process, hence an emphasis on a play-based approach to learning (Moyles 2010). Pedagogy is about children having agency in their own learning, participating fully and co-constructing knowledge (Vorwerk 2009). Learning is therefore democratic, context sensitive and child-centred. Furthermore, a relevant education is not limited to a classroom, but seeks to contextualise issues within the geographical, social and cultural context of a community (Vonta 2000). The policies discussed here acknowledge the role of the family and community, the agency of the child and the need to be context adaptive. A teacher who adopts the 10 competencies proposed in PMRP (DHET 2017) will be reflective and able to problem solve to meet the challenges of their teaching and learning contexts. In practice, this means teachers reflect on their daily performance and issues that arise and are capable of finding solutions to what are often challenging circumstances.

Although the attitude of government and training organisations has been to improve the quality of ECCE, there is still much work to be done to implement policy effectively. This will require a more sensitive approach to context, together with an openness to considering that current approaches are not always effective (Ward 2006).

\section{Research methods}

A desktop survey and research report are a non-invasive way of gathering and reporting on data with a view to informing a particular situation (Collins Dictionary 2019). It addresses information that is already available; therefore, ethics are not a significant issue. It allows use of existing information to answer general questions, in this case questions such as the location of ECCE training institutions in South Africa. The purpose of the research report was to inform programme and qualification development for birth-to-four diplomas and degrees. Data gathered on institutional offerings would additionally form a database on the South African Research Association for 
Early Childhood Education (SARAECE) website where prospective students can browse to find where and how they might wish to study ECCE.

\section{Research questions}

The main research question driving this desktop study was: What ECCE training is available in South Africa and where are the relevant institutions located?

Subsidiary research questions were:

- How is access to ECCE training distributed regionally?

- What does the literature say about training in ECCE?

- What do the findings indicate with regard to programme and qualification development for the birth-to-four age group, and professionalisation of this sector?

\section{Data collection and analysis}

The literature review and collaborative work of this desktop study used consultants drawn from a variety of HEIs. The consultants were chosen in some instances because of the T\&LDCIP programme that they co-ordinated, and because of their areas of specialisation. For example, one consultant had a long track record of publication in the ECCE sector; another had recently completed research specific to ECCE and another worked on the TP Project, thereby bringing current expertise to bear. Additional data were collected by means of an online survey administered through the PIECCE project using the Internet to access information on institutional offerings.

Information was captured on a spreadsheet and, over a period of 2 months, each institution was telephoned or emailed to confirm relevance of the information. If an institution was not responsive, they were omitted from the list. Further information was gathered from BRIDGE who had conducted a survey of resource training organisations (RTOs), ${ }^{2}$ and this information was used to supplement the spreadsheet. Finally, data from Survey One of the PIECCE project (ed. Harrison 2017) were used to understand some of the programmes on offer and whether they were specific to ECCE.

As this study made use of participatory action research (Creswell \& Clark 2007; Patton 2015) the data were checked and assessed with the research team at intervals to ensure that necessary adjustments were made. This included making a decision to omit non-current information from the database; further updating NGO information; choosing to highlight only a selection of NGOs; and re-evaluating what maps to include in the report (ed. Harrison 2018).

\section{Findings}

The findings of the desktop study (ed. Harrison 2018) initially focussed on the geographic distribution of training institutions relevant to ECCE or ECD. (For the purposes of this study, ECD is included within ECCE.) The research aimed to clarify information about available ECCE programmes across three types of training institution, namely NGOs, TVETs and HEIs. This speaks to the first research question which sought to establish the level of access for students wanting to study early childhood education.

\section{Distribution}

To understand where the gaps are and to evaluate access to ECCE training in terms of institutional offerings, the distribution of relevant training institutions was surveyed. Each type of institution, namely NGO, TVET and HEI, was surveyed using Internet searches, document analysis and research reports. The study noted geographical location and assessed accessibility and issues specific to each type of training institution. The Non-governmental organisations section of this article looks at each type of training institution in relation to distribution, programme offerings and other issues specific to the type of institution.

\section{Non-governmental organisations}

The desktop study did a document analysis by using information gathered by $\mathrm{BRIDGE}^{3}$, an NGO dedicated to providing bridging information across multiple stakeholders involved in ECCE, and information gathered by one of the oldest NGOs in South Africa, namely the Centre for Early Childhood Development ${ }^{4}$ (CECD), who conducted their own survey in 2016. Where there are differences between the two sets of data, it is attributable to the step that the desktop study took to contact the NGOs or RTOs to confirm their currency and whether they were offering any training or support specific to the birth-to-four age group. This led to some RTOs being identified as no longer relevant. Table 1 shows the provincial distribution of NGOs that offer training in ECD.

The provinces with the greatest concentration of NGOs offering ECCE training are Gauteng and Western Cape. Both these provinces also featured prominently in obtaining the best matric results, which suggests that early intervention does have an impact on later academic performance. (This pattern is outside the scope of this article, but calls for focussed research.) Early Childhood Care and Education training at NGOs was poorly provided for in North West and Northern Cape provinces and was generally very unevenly distributed across the country.

The study found that many NGOs had poor websites, out-ofdate contact information, and did not respond to emails and phone calls. Non-governmental organisations need to be mindful of these aspects of professionalism if they wish to survive in a highly competitive market.

\footnotetext{
3 BRIDGE works with multiple stakeholders in the ECD sector to assist in buildin understanding of the sector and collaborative effort (https://www.bridge.org.za/).

4.Centre for Early Childhood Development has worked in the ECD sector since 1994 and continues to contribute to the development of policy and quality ECD training.
} 
TABLE 1: Numbers of non-governmental organisations or resource training organisations offering early childhood care and education training, per province.

\begin{tabular}{lcc}
\hline Province & CECD data & Desktop study data \\
\hline Gauteng & 20 & 20 \\
Western Cape & 17 & 17 \\
Eastern Cape & 13 & 10 \\
KwaZulu-Natal & 8 & 8 \\
Free State & 10 & 5 \\
Limpopo & 6 & 6 \\
Mpumalanga & 5 & 4 \\
Northern Cape & 2 & 2 \\
North West & 0 & 0 \\
\hline Totals & $\mathbf{8 1}$ & $\mathbf{7 2}$
\end{tabular}

CECD, Centre for Early Childhood Development.

\section{Technical and vocational education and trainings}

The purpose of attending a TVET, as opposed to an HEI or $\mathrm{NGO}$, is that the emphasis is placed on a specific range of vocational jobs, potential employment and entrepreneurial possibilities (Aller et al. 2009). According to the TVET colleges of South Africa website, there are 50 registered and accredited TVET colleges operating over at least 264 campuses in South Africa, in both urban and rural areas. The public TVET colleges operate according to the Continuing Education and Training Act 16 (DHET 2006) and under the authority of the DHET. This desktop study found that, out of 50 registered TVETs, 21 offered some type of training in ECCE.

The researcher examined the offerings of a National Certificate or Diploma in Educare, as this content was closest to the ECCE domain. Of the 21 TVETs, 33 campuses offered ECCE training (Table 2). The uneven geographical distribution of TVETs is striking. The types of ECCE career opportunities that were listed across a variety of TVETS included 'early childhood development assistant', 'playgroup practitioner', 'early childhood development practitioner', 'au pair', 'day-mother' and 'entrepreneurial'.

Arising from discussions and interviews with TVET representatives at an Indaba held at Rhodes University in February 2016, it became evident that there are two problem areas when offering ECCE training, namely capacity in the form of appropriately qualified and skilled staff and availability of materials.

Many of the portfolio heads at TVETs are responsible for multiple portfolios, which are often unrelated. The amount of attention they can give to any particular portfolio is limited. In addition, portfolio heads are not necessarily trained in a particular portfolio, which may have been assigned to them by default. Furthermore, there was evidence that TVETs struggle to attract relevant ECD teaching staff and that existing staff are sometimes under-qualified.

With regard to the issue of ECCE training materials, TVETs themselves generally do not develop their own materials, possibly as a result of lack of capacity, and therefore purchase materials externally. This presents problems of
TABLE 2: Technical and vocational education and trainings campuses offering early childhood care and education by province.

\begin{tabular}{lcl}
\hline Provinces & $\begin{array}{l}\text { No. of TVET } \\
\text { campuses } \\
\text { offering ECCE }\end{array}$ & Comments \\
\hline Western Cape & 11 & Fairly well spread; none near Northern Cape \\
Gauteng & 6 & Mainly in the west; none near Mpumalanga \\
Free State & 5 & Fairly well spread \\
KwaZulu-Natal & 4 & Mainly at the coast; only one in Zululand \\
Limpopo & 3 & Fairly well spread \\
Eastern Cape & 2 & Only East London and Mthatha \\
North West & 2 & Only in the east, near Gauteng \\
Mpumalanga & 0 & None \\
Northern Cape & 0 & None \\
\hline Total & 33 & Highly uneven distribution \\
\hline ECCE, early childhood care and education; TVET, technical and vocational education and \\
trainings.
\end{tabular}

capital expenditure and an inconsistency in quality of teaching materials.

These negative factors could be improved by closer collaboration with NGOs that have the capacity to assist with training and have materials, which they have developed over several years (ed. Harrison 2017).

When addressing private TVETs, ${ }^{5}$ it was more problematic to ascertain what training was taking place in ECCE. Contacting private service providers was challenging owing to dysfunctional websites, unanswered telephones and outdated contact details. The few that were successfully contacted indicated that they did not offer specific ECCE training. Some stated that they used to offer the FETCs NQF Levels 4 and 5, but no longer offered these owing to lack of interest, capacity or funds. One had started offering the new NQF QCTO (Quality Council for Trades and Occupations) Level 3 course, which is intended to bridge Levels 1 and 4 . It would appear that private TVETs come and go and that there is a need to monitor this type of TVET more rigorously.

As in the case of public TVETs, the use of training materials was problematic and private TVETs were reluctant to share information on the sources of their training materials. Quality issues related to TVETs' service delivery in ECCE are potentially problematic. When practitioners from a TVET wish to progress to a qualification at an HEI, they do not necessarily have sufficient credits or grounding to cope with the demands of a degree, thereby limiting accessibility across teacher-training institutions (ed. Harrison 2017). This underlines the importance of bringing multiple stakeholders in ECCE together to explore how they can support one another and ensure quality training.

\section{Higher education institutions}

Higher education institution refers specifically to universities and, as found in the PIECCE baseline study (ed. Harrison 2017), it was evident that they do not yet have a focus on the birth-to-four age group as a specialisation. Through 5.A private TVET is understood to be one that is independent of government-funded TVETs. 
development of the PMRP (DHET 2017) document, and with funding from the European Union, a number of HEIs are now developing either a relevant diploma or degree. The desktop study showed that there appears to be a preference for a diploma as there is a perception that it would attract better uptake than a degree. This is based on the idea that a diploma is less demanding and therefore more suitable for the type of student that might want to study further to improve earning power.

What is evident from the PIECCE report (ed. Harrison 2017) is that HEIs have not completely ignored the birth-to-four phase of development when implementing their training, but it generally forms part of a module on ECD. Only one university, namely Rhodes, offers FETC NQF Levels 4 through 7 qualifications that are specific to ECD, thus providing a career path that allows practitioners to move from the most basic qualification in ECCE, to potentially progressing to a $\mathrm{PhD}$. The remaining nine universities in the PIECCE project included ECD modules in their FP qualifications and Grade $\mathrm{R}$ diplomas. Development of a diploma or degree in the birth-to-four phase is founded on knowledge and practice standards derived from the PMRP (DHET 2017) policy document, with a view to a national standardised curriculum to maintain quality across training institutions.

Limpopo and Mpumalanga lack a relevant HEI, and Northern Cape has only one, in Kimberley (Table 3). There is a concentration of HEIs in, or close to, Gauteng. In Western Cape, HEIs are clustered around Cape Town, with the rest of the province devoid of them. KwaZulu-Natal, Free State and North West have only two HEIs each. In KwaZulu-Natal, Durban has both of the province's HEIs. (University of KwaZulu-Natal absorbed the University of Durban Westville and has campuses in Westville and Pinetown.) Eastern Cape has four HEIs, which are relatively evenly spread across the province. Keeping in mind that much of the training in ECCE has traditionally been by NGOs, which have a wider geographical spread, the geographical distribution of HEIs and TVETs is not necessarily a problem for prospective students, unless they specifically want a diploma or degree.

What inevitably influences uptake at a training institution are costs of fees and accommodation. A recent informal

TABLE 3: Higher education institutions (universities or campuses) offering early childhood care and education, by province.

\begin{tabular}{lc}
\hline Provinces & No. of HEl campuses offering ECCE training \\
\hline Eastern Cape & 4 \\
Western Cape & 3 \\
Gauteng & 3 \\
Free State & 2 \\
KwaZulu-Natal & 2 \\
North West & 2 \\
Northern Cape & 1 \\
Limpopo & 0 \\
Mpumalanga & 0 \\
\hline Total & $\mathbf{1 7}$ \\
\hline
\end{tabular}

HEI, higher education institutions; ECCE, early childhood care and education. study done by Rhodes University found that many nonreturning students had decided to study closer to home to reduce costs.

\section{Types of courses offered in early childhood care and education}

The desktop study (ed. Harrison 2018) surveyed the literature to provide an overview of the types of courses available to teachers in ECCE, and how they were configured. This was to better understand the relevance of a birth-to-four diploma or degree and describe the gaps. Drawing from data in the PIECCE report (ed. Harrison 2017) and online data, the following facts became evident.

The FETC ECD Level 4 qualification is primarily offered by NGOs and is considered an important foundation for any teacher wishing to pursue a career in ECCE. In the 2014 examination of qualifications by the QCTO, it became clear that an earlier, more fundamental qualification is necessary for teacher assistants, hence the development of a Level 3 -accredited course. The reason for this was that teachers in the ECCE sector require a transitional year from their formal schooling into tertiary education.

The PIECCE report (ed. Harrison 2017) and the desktop study (ed. Harrison 2018) found that the Level 4 qualification is traditionally offered by NGO and TVET sectors, with a total of 21 TVETs and 72 NGOs offering some form of ECCE training. As noted earlier, the certificate or diploma in Educare offered by TVETs could be considered the most relevant qualification linked to ECCE, as 'Educare' combines the concepts of 'education' and 'care', which are both seen to be at the heart of a birth-to-four qualification. The Educare curriculum covers topics such as 'day-care communication', 'child health', 'day-care management', 'didactics theory and practice', 'early childhood development', 'human and social development', 'learning psychology', 'day-care administration' and 'personnel management'. The course is graded over 3 years and allows participants to move from a Certificate (Y1, N4) to a Higher Certificate (Y2, N5) to a full Diploma in ECD (Y3, N6).

In the NGO sector, through a concerted effort to consolidate training materials and promote use of quality materials, it was decided by the National Early Childhood Development Alliance (commonly referred to as 'the Alliance' within the NGO sector because it consists of a group of ECD NGOs) to develop materials that could be used to train NQF Levels 4 and 5. A team of experts in the field was formed and the Alliance materials were realised in 2012. A variety of NGOs participated in the development of the materials, including CECD, Early Learning Research Unit (ELRU), Khululeka, Training and Resources in Early Education (TREE), LETCEE and Ntataise Trust. It is primarily the Level 4 qualification, consisting of 11 modules, that concerns the birth-to-four sector, providing a foundation of knowledge for the ECCE practitioner, starting with the youngest children in their care. Topics covered include 'provide care for children', 'families 
and communities', 'observe and report on child development' and 'prepare ECD programmes'.

It was interesting to note that some HEIs offered the FETC Level 5 qualification as it can potentially allow HEIs to control the quality of applicants that go on to apply for a Grade R diploma or in-service BEd FP (ed. Harrison 2017). The FETC ECD Level 5 qualification was also offered by NGOs and, to a lesser extent, TVETs. It is a longer course, lasting 18 months to 2 years, whereas Level 4 is often a 1-year only course. The Level 5 qualification provides a more substantive knowledge base for an ECCE teacher or practitioner and is often delivered as an in-service model. The advantage of having the Level 5 qualification is that the applicant can progress into a Grade $\mathrm{R}$ diploma or in-service BEd FP.

A limitation of the desktop study was the examination of training materials for Levels 4 and 5, which was problematic, as training institutions did not agree to share their content. For this reason, the desktop study could speak only to the Alliance materials which are used across a variety of NGOs, which generally do the majority of the relevant training. As is the case with Level 4, Level 5 contained modules that covered the birth-to-four age group, but in only 4 of the 12 modules that make up the course. Topics covered in Level 5 included 'child development', 'designing activities for young children', 'health and safety' and 'literacy and numeracy for the young child'. Both the Level 4 and 5 courses placed some emphasis on play and a child-centred approach to pedagogy, but this varied with the materials used by institutions. Most teachertraining NGOs had a non-accredited course on 'babies and toddlers' offered to parents and practitioners.

The Diploma in Grade $\mathrm{R}$ is a specialised qualification as it deals specifically with training students or practitioners for the unique year of Grade R. Grade R is the year that precedes Grade 1 and its purpose is to instil foundational knowledge that facilitates learning from Grade 1 to Matric. It should be noted that, in the sample taken for this report, only one HEI (North West University) offered a Diploma in Grade R and that, in 2015, the DBE indicated that there were only four HEIs offering this qualification, despite there being a need for $78 \%$ of all Grade $\mathrm{R}$ in-service teachers to receive training. The Diploma in Grade R, an NQF Level 6 qualification, was developed to meet specific needs in SA's education system post-1994 and was part of the government's drive to make Grade $\mathrm{R}$ available to as many children as possible.

According to Taylor (2014), by 2011, 80\% of children had access to Grade $\mathrm{R}$, but it had limited impact on later educational development. Taylor attributed this to the need to improve the quality of programmes on offer, especially in impoverished communities. 'Quality is key: a quality curriculum; a quality teacher; a quality response to developmental needs' (Taylor 2014:2). He suggested that this could be achieved by advocating professionalism in ECD and practical, in-service teacher support, particularly in assessment strategies and foundational literacy.
Although the Grade R diploma is a Level 6 qualification, the BEd FP is a Level 7 qualification and sits comfortably within an HEI context. It is therefore not surprising that NGOs do not usually offer this qualification, with the exception of Rhodes University that offers an in-service version through the Centre for Social Development (an NGO under the Education Faculty). Technical and vocational education and trainings are not able to offer a degree unless they collaborate with a university. It is interesting to note that, in the PIECCE project, obtaining TVET 'buy-in' to offer a birth-to-four diploma or degree was problematic in terms of sustained participation in the research and programme development.

Six of the 10 universities that were approached about their institutional offerings indicated that they have a BEd FP on their books. Only Rhodes University offers an in-service, part-time, contact session-based model. With the drive for teachers who are already qualified to demonstrate a 4-year qualification and improved knowledge, the BEd FP qualification has gained popularity. The negative effect, however, is that many teachers who begin the qualification as teachers of Grade R leave the grade to teach higher grades or become learning-area specialists or district managers. The effect of this is that teachers who receive quality training do not necessarily use it in the classroom.

The obvious gap in teacher training is that of the birth-to-four age group, hence the drive to professionalise the sector by offering a diploma or degree that is specific to ECCE.

\section{Where does the emphasis currently lie in terms of content covered in early childhood care and education?}

The purpose of this article is not to undertake a detailed analysis of materials used and content presented, but it is nevertheless important to make some comments in this regard. Firstly, as mentioned, training institutions were not keen to divulge what training materials they use or how they access them, and these practices also vary between institutions. As materials development is costly and time-consuming, it is not surprising that training institutions are protective of their resources. However, a positive aspect of the multi-stakeholder approach that emerged from the PIECCE project was a greater sharing of knowledge, resulting in NGOs with a long history of training in the birth-to-four age group sharing their knowledge and video libraries with HEIs. HEIs that have a more theory-based approach were prepared to discuss materials development and strategies with NGOs and to visit NGOs to see how training is implemented at birth-to-four learning sites. Technical and vocational education and trainings appeared to buy in their materials as they did not have the capacity to develop them. Non-governmental organisations developed a great deal of their materials inhouse, but also made use of Alliance materials that were developed by an NGO for the NGO sector, whereas HEIs chose to develop their own course materials, drawing from the collective knowledge of lecturers working on BEd programmes. 
It would appear, therefore, that content that is specific to birth-to-four diploma or degree programmes is available through the NGO sector, and that a collaboration between NGOs and HEIs could lead to development of rich and relevant materials that allow for practical, tried-and-tested methods, combined with strong theoretical approaches. Technical and vocational education and trainings should be capacitated to develop materials and they should consider collaborating with HEIs and NGOs in the process of developing a birth-to-four diploma or degree. Work of organisations such as BRIDGE is invaluable to this process of multi-stakeholder engagement, as their communities of practice provide a platform for engagement by various stakeholders and a sharing of expertise.

More recent emphasis on play-based learning and development of the EU-funded, online PLAY (Powerful Learning Around You) programme, together with a child-centred curriculum, provide a direction for training institutions involved in the programme framework for birth-to-four diploma or degree programmes. As current training materials often only touch on these focus areas, it is useful to know that there are already support materials and concepts available.

This desktop study revealed that a more pressing issue, however, is articulation between qualifications and how this may affect the birth-to-four diploma or degree programmes and their materials development and usage. Without a clear understanding of how the qualifications interrelate and articulate in the NQF for career advancement or specialisation, it is difficult to pitch the level of training materials so that teachers acquire cumulative and appropriate knowledge and competency for centre-based effective teaching and learning.

\section{Conclusion}

Issues related to accessing ECCE training have been described, both geographically and in terms of articulation between qualifications and entrance requirements between institutions. Although policies suggest strategies for quality ECCE, implementation is hampered by the way in which teachertraining institutions develop materials, lack of standardisation of priority knowledge in ECCE and the dysfunctionality of ETDP SETA that results in non-issuance of certificates.

It is evident that there is a positive will for the multidisciplinary ECCE sector to work together. A suggested way forward is for various initial teacher-training organisations (ITTOs) to collaborate on the development of materials and on-site visits to practitioners, to ensure that implementation of theory takes place at the level of practice, and thereby to promote TP. Further stakeholder collaboration should take place in articulating qualifications between ITTOs and the implications of a professionalised ECCE sector operating in varied socio-economic contexts.

Although recognition of the importance of the first 1000 days has led to a desire to professionalise the ECCE sector, this snapshot shows that much remains to be done to deliver quality ECCE to the children of South Africa.

\section{Acknowledgements}

This paper would not be possible without the contributing authors of both the PIECCE Report (Harrison, 2017) and Desktop Study (Harrison, 2018). I therefore gratefully acknowledge K. Bipath, P. Clarke, M. Clasquin-Johnson, G. Daries, S. Drew, H. Ebrahim, L. Excell, G. Galloway, S. Greyling, D. Hannaway, S.M. Madingoeaneng, B. Magoge, N. Makwetu, C. Mantlana, C.D. Martin, N. Mashiya, S. McGuigan, M. Modise, A. Morris, P. Motsoeneng, T. Phala, N. Shaik, L. Stretch, M. Vermaak and A. Watermeyer.

\section{Competing interests}

The author declares that she has no financial or personal relationships that may have inappropriately influenced her in writing this article.

\section{Author's contributions}

G.D.H. declares that she is the sole author of this research article.

\section{Ethical consideration}

This article followed all ethical standards for a research without direct contact with human or animal subjects.

\section{Funding information}

This paper received funding from the Department of Higher Education and Training through the European Union.

\section{Data availability statement}

This was a desktop study and by its very nature was drawing from existing data available to all researchers.

\section{Disclaimer}

The views and opinions expressed in this article are those of the authors and do not necessarily reflect the official policy or position of any affiliated agency of the authors.

\section{References}

Aller, F., Christie, P., Excel, L. \& Linnington, V., 2009, Implementation of the nationa curriculum statement in the foundation phase. Composition, South Africa, Gauteng Department of Education, Pretoria.

Berry, L., Dawes, A. \& Biersteker, L., 2013, 'Getting the basics right: An essential package of services and support for ECD', in L. Berry, L. Biersteker, A. Dawes, L. Lake \& C. Smith (eds.), Child gauge, UCT \& The Children's Institute, Cape Town.

Biersteker, L., 2007, Rapid assessment and analysis of innovative community and home based childminding and early childhood development programmes in support of poor and vulnerable children in South Africa, UNICEF, Pretoria, viewed 05 July 2020 from https://www.unicef.org/southafrica/sites/unicef.org.southafrica/files/201907/ZAF-early-childhood-development-2007.pdf

Biersteker, L., 2008, 'A review of training qualifications, training provision and training delivery in relation to the needs of the National Integrated Plan for ECD and the ECD component of the Expanded Public Works Programme', paper developed for the HSRC Scaling Early Childhood Development (0-4 years) Research Project, HSRC Press, Pretoria, Cape Town, South Africa. 
Biersteker, L. \& Picken, P., 2013, Report on a survey of non-profit organisations providing training for ECD programmes and services (birth to four years), llifa providing training for $\mathrm{ECD}$
Labantwana, Cape Town

BRIDGE, 2016, The ECD quality toolkit pilot project, BRIDGE, Johannesburg, viewed 18 March 2020, from https://www.bridge.org.za/wp-content/uploads/2016/11/ECDQuality-Toolkit-Pilot-Report-20161115-Bridge-version.pdf.

Britto, P.R., Yoshikawa, H. \& Boller, K., 2011, 'Measuring quality and using it to improve practice and policy in early childhood development', in Sharing child and youth development knowledge, vol. 25, p. 2, viewed from http://www.srcd.org/sites/ default/files/documents/spr_v252rev.pdf.

Brock, T., 2010, 'Young adult and higher education: Barriers and breakthroughs to success', The Future of Our Children 20(1), 109-132, viewed 24 March 2020, from https://doi.org/10.1353/foc. 0.0040

Collins Dictionary, 2019, Collins English dictionary and thesaurus, Harper Collins, Glasgow.

Creswell, J. \& Clark, V.L.P., 2007, Designing and conducting mixed methods research, Sage, Thousand Oaks, CA.

Dahlberg, G., Moss, P. \& Pence, A., 2013, Beyond quality in early childhood education and care: Languages of evaluation, Routledge, London.

Department of Basic Education [DBE], 2001, White paper 6, Department of Basic Education, Pretoria, viewed 1 October 2019, from https://www.education.gov.za/ Portals/0/Documents/Legislation/White\%20paper/Education\%20\%20White\%20 Paper\%206. pdf?ver=2008-03-05-104651-000.

Department of Basic Education [DBE], 2011, National Curriculum Statement (NCS) curriculum and assessment policy statement (CAPS), Grades R-3, Department of Basic Education, Pretoria.

Department of Basic Education [DBE], 2015a, Basic education on improving qualifications for grade $R$ teachers, Department of Basic Education, Pretoria, viewed 2 February 2017, from http://www.gov.za/speeches/department-basiceducation-working-hard-improve-qualifications-grade-r-teachers-4-aug-2015.

Department of Basic Education [DBE], 2015b, The South African national curriculum framework for children from birth to four years, Department of Basic Education, Pretoria.

Department of Basic Education [DBE] \& UNICEF, 2009, National early learning and development standards for children birth to four years (NELDS), Department of Basic Education, Pretoria, viewed 6 August 2017, from https://www.unicef.org/ southafrica/media/1746/file/ZAF-national-early-learning-and-developmentstandards-for-children-birth-to-4-years-2011.pdf

Department of Education [DoE], 2001, Nationwide audit of ECD provisioning, Department of Education, Pretoria.

Department of Health and Welfare [DHW], 2003, National health act 60, Department of Health and Welfare, Pretoria.

Department of Higher Education and Training [DHET], 2006, Continuing education and training act 16, Department of Higher Education and Training, Pretoria, viewed 24 January 2020, from http://www.dhet.gov.za/Community/national\%20policy\%20 on\%20community\%20colleges.pdf.

Department of Higher Education and Training [DHET], 2011, Minimum requirements for teacher education qualifications, Department of Higher Education and Training, Pretoria.

Department of Higher Education and Training [DHET], 2015, Revised policy on the minimum requirements for teacher education qualifications, Department of Higher Education and Training, Pretoria, viewed 8 March 2016, from http://www. dhet.gov.za/Teacher\%20Education/National\%20Qualifications $\% 20$ Framework\%20Act\%2067 2008\%20Revised\%20Policy\%20for\%20Teacher\%20 Education\%20Quilifications.pdf.

Department of Higher Education and Training [DHET], 2017, Policy on the minimum requirements for programmes leading to qualifications in higher education for early childhood development educators, Government Gazette No. 40750, 31 March 2017, Department of Higher Education and Training, Pretoria.

Department of Justice, 2005, The children's act no. 38, Department of Justice, Pretoria viewed 10 October 2018, from https://www.google.co.za/webhp?sourceid=chromeinstant\&rlz=1C1CAFA_enZA657ZA657\&ion=1\&espv=2\&ie=UTF-8\#q=the+children's + act+no+38+of+200

Department of Social Development [DSD], 2005, Children's Act No. 38, Department of Social Development, Pretoria, viewed 28 March 2020, from https://www. westerncape.gov.za/Text/2010/12/childrens.act.final_regulations26_jan_2010.pdf.

Department of Social Development [DSD], 2006, Guidelines for early childhood development services, Department of Social Development, Pretoria, viewed 28 March 2020, from https://www.google.co.za/webhp?sourceid=chromeinstant\&rlz=1C1CAFA_enZA657ZA657\&ion $=1 \&$ espv $=2 \&$ ie $=U T F-8 \# q=$ Guidelines $+f$ or+Early+Childhood+Development+Services.+2006.+Department+of+Social+Dev elopment:+Pretoria.

Department of Social Development [DSD], 2014, Audit of early childhood developmen (ECD) centres: National report, Department of Social Development, Pretoria, viewed 28 March 2020, from http://www.dsd.gov.za/index2.php?option=com docman\&task=doc_view\&gid=608\&ltemid=39.

Department of Social Development [DSD], 2015, National integrated early childhood development policy, Department of Social Development, Pretoria, viewed 27 April 2020, from https://www.google.co.za/webhp?sourceid=chromeinstant\&rlz=1C1CAFA_enZA657ZA657\&ion=1\&espv=2\&ie=UTF-8\#q=Guidelines for+Early+Childhood+Development+Services.+2006.+Department+of+Social+ Development:+Pretoria.

Ebrahim, H.B., 2010, 'Mapping historical shifts in early care and education in South Africa', Journal of Education 48, 119-135.
Ebrahim, H.B., Killian, B. \& Rule, P., 2011, 'Practices of early childhood development practitioners for poor and vulnerable children from birth to four years in South practitioners for poor and vulnerable children from birth to four years in South
Africa', Early Child Development and Care 181(3), 387-396, viewed 27 April 2020, from https://doi.org/10.1080/03004430903392602

Ebrahim, H.B., Okwany, A. \& Barry, O. (eds.), 2019, Early childhood care and education at the margins, Routledge, London, viewed 28 April 2020, from https://doi. org/10.4324/9781351185158

Ebrahim, H.B., Seleti, J. \& Dawes, A., 2013, 'Learning begins at birth: Improving access to early learning', in L. Berry, L. Biersteker, A. Dawes, L. Lake \& C. Smith (eds.) Child gauge, UCT \& The Children's Institute, Cape Town, pp. 153-157.

ETDP-SETA, 2012, ECD sector skills plan. 2013/2014 update, viewed 28 April 2020, from www.etdpseta.org.za.

Freire, P., 1970, Pedagogy of the oppressed. Herder and Herder, New York.

Harrison, G.D. (ed.), 2017, PIECCE report, Centre for Social Development, Rhodes University, Grahamstown.

Harrison, G.D. (ed.), 2018, Desktop study of ECCE offerings, Centre for Social Development, Rhodes University Grahamstown.

HSRC \& ELRU, 2010, Western Cape Department of Social Development 2009 audit ECD facility quality, Human Sciences Research Council, viewed 27 March 2020, from https://www.westerncape.gov.za/text/2010/6/hsrc-qualitativeassessment-ecdfinal_report-22-02-10.pdf.

Ilifa Labantwana, 2017, South African early childhood review 2017, Ilifa Labantwana, Cape Town, viewed 06 July 2018, from http://ilifalabantwana.co.za/wp-content/ uploads/2017/10/SA-ECR_2017_WEB-new.pdf.

Jansen, J., 2012, Education crisis a threat to democracy, viewed 24 March 2020, from https://www.polity.org.za/article/education-crisis-a-threat-to-democracyjonathan-jansen-2012-11-23.

Khosa, P. \& Kaseke, E., 2017, 'The utilisation of the child support grant by caregivers: 'The case of Ba-Phalaborwa municipality in Limpopo Province', Social Work, 53(3). https://doi.org/10.15270/53-3-575

Mbarathi, N., Mthembu, M. \& Diga, K., 2016, Early childhood development and South Africa: A literature review, University of KwaZulu-Natal, Durban.

Moyles, J., 2010, Thinking about play: Developing a reflective approach, Open University Press, Berkshire.

Mullis, I.V.S., Michael, O., Martin, M.O., Foy, P. \& Hooper, M., 2017, PIRLS 2016 international results in reading, viewed 27 March 2020, from http://timssandpirls. bc.edu/pirls2016/international-results/pirls/summary/.

Peralta, M., 2008, 'Quality: Children's right to appropriate and relevant education. Early Childhood Education Matters, 110, 3-12.

Patton, M.Q., 2015, Qualitative research and evaluation methods, 4th edn., Sage, New York, NY.

QCTO, 2014, Taking root and settling in: Annual report, viewed 27 April 2020, from http://www.qcto.org.za/images/reports/qctoreport2015.pdf.

Richter, L. 2013, p.7 'Foreword', in L. Berry, L. Biersteker, A. Dawes, L. Lake \& C. Smith (eds.), Child gauge, UCT \& The Children's Institute, Cape Town.

Richter, L., Biersteker, L., Burns, J., Desmond, C., Feza, N., Harrison, D. et al., 2012 Diagnostic review of early childhood development, Human Science Research Council, Pretoria.

RSA, 1996, Constitution of the Republic of South Africa (Act 108 of 1996), Government Printers, Pretoria.

RSA, 2014, Audit of early childhood development (ECD) centres, National Report, Department of Social Development, Pretoria.

RSA, 2015, National integrated early childhood development policy, Government Printers, Pretoria.

South African Qualifications Authority (SAQA), 2008, NQF history, South African Qualifications Authority, Pretoria, viewed 10 April 2017, from http://www.saqa. Qualifications Authority, Preto
org.za/show.php?id=5659.

Spaull, N., 2013, South Africa's education crisis: The quality of education in South Africa 1994-2011, viewed 28 March 2020, from Centre for Development and Enterprise, Johannesburg.

Stats SA, 2015, General household survey 2014, Statistics SA, Pretoria.

Taylor, S., 2014, Policy brief: Strengthening the impact of the Grade R programme, viewed 15 April 2020, from http://www.education.gov.za/Portals/0/Documents/Reports/ Policy\%20Brief\%20Impact\%20of\%20introduction\%20of\%20Grade\%20R.pdf.

UNICEF, 2017, UNICEF annual report, viewed 24 January 2020, from https://www.unicef. org/publications/index_102899.html.

Viviers, A., 2014, Child rights: Key international treaties in the promotion, protection and fulfilment of children's rights, UNICEF, viewed 28 April 2020, from https:// www.unicef.org/southafrica/SAF_resources_basicchildrightstreaties.pdf.

Vonta, T., 2000, 'Quality indicators in preschool education. Ways towards quality in education', in Conference proceedings, April 8-10, viewed 28 April 2020, from http://www.fm-kp.si/zalozba/ISBN/961-6268-47-3/175-182.pdf.

Vorwerk, C., 2009, 'Curriculum for skills development', Skills at Work: Theory and Practice Journal 2(1), 83-118.

Ward, N.L., 2006, 'Improving equity and access for low-income and minority youth into institutions of higher education', Urban Education 41, 50-70. viewed 22 March 2020, from https://doi.org/10.1177/0042085905282253

Wood, E., 2009, 'Developing a pedagogy of play', in A. Anning, J. Cullen \& M. Fleer (eds.), Early childhood education: Society and culture, pp. 27-38, Sage, London. 